\title{
Map numbers (all on bottom map)
}

1 Anne Arundel County

2 Calvert County

3 South Mountain

4 Oakland

5 Swallow Falls State Park

6 Silver Lake

7 Backbone Mountain

8 Fairfax Stone

9 Bethany Beach

10 Rehoboth Beach

11 Burton's Island

12 Indian River Inlet

13 Huntley Meadows Park

14 Violette's Lock

15 McKee-Beshers Wildlife Management Area

16 Pennyfield Lock

17 Cape Henlopen

18 Randle Cliff

19 Chesapeake Beach

20 Mount Vernon

21 Little Bennett Regional Park 


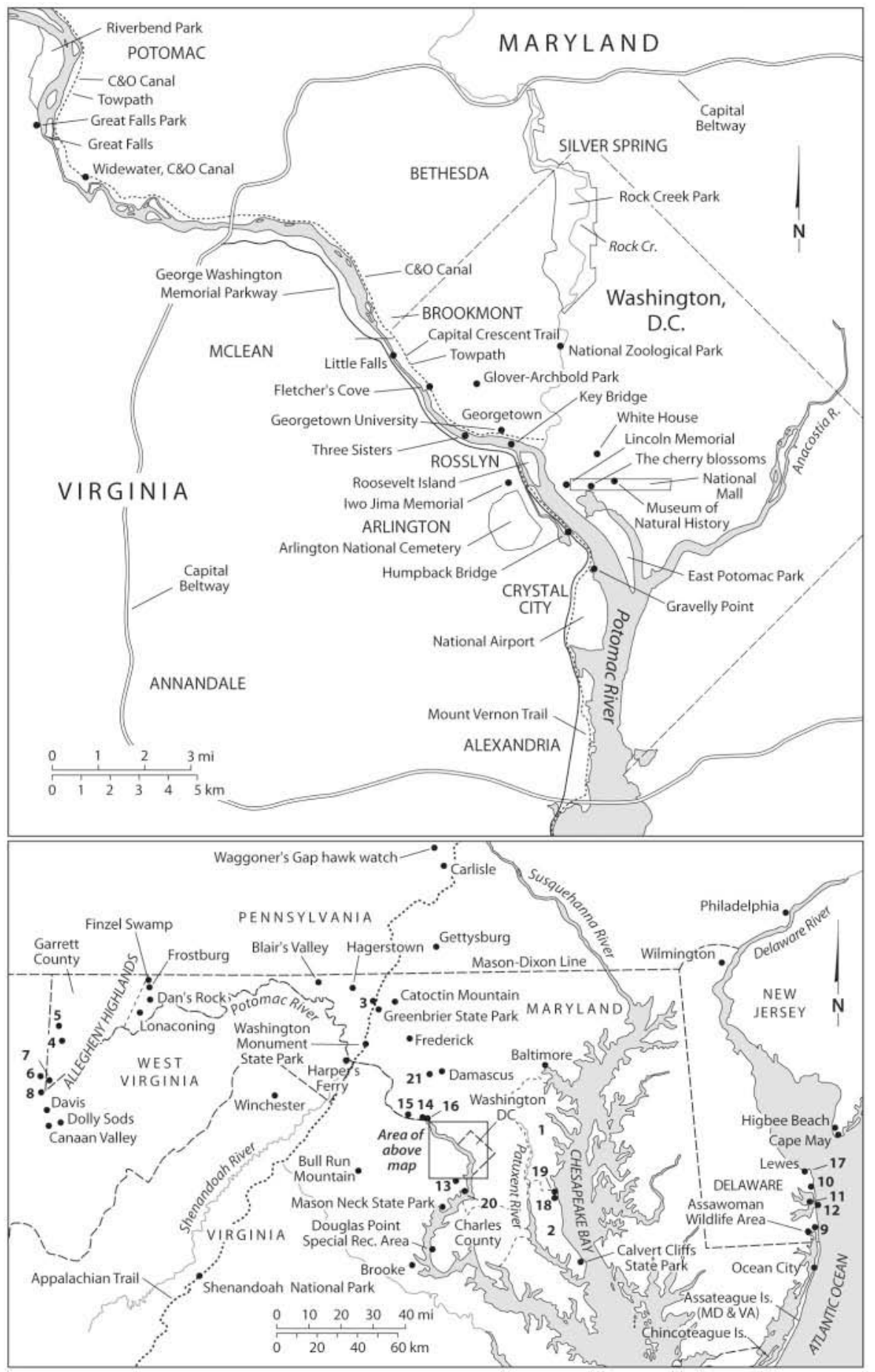

Locator map for Washington, DC, and environs 


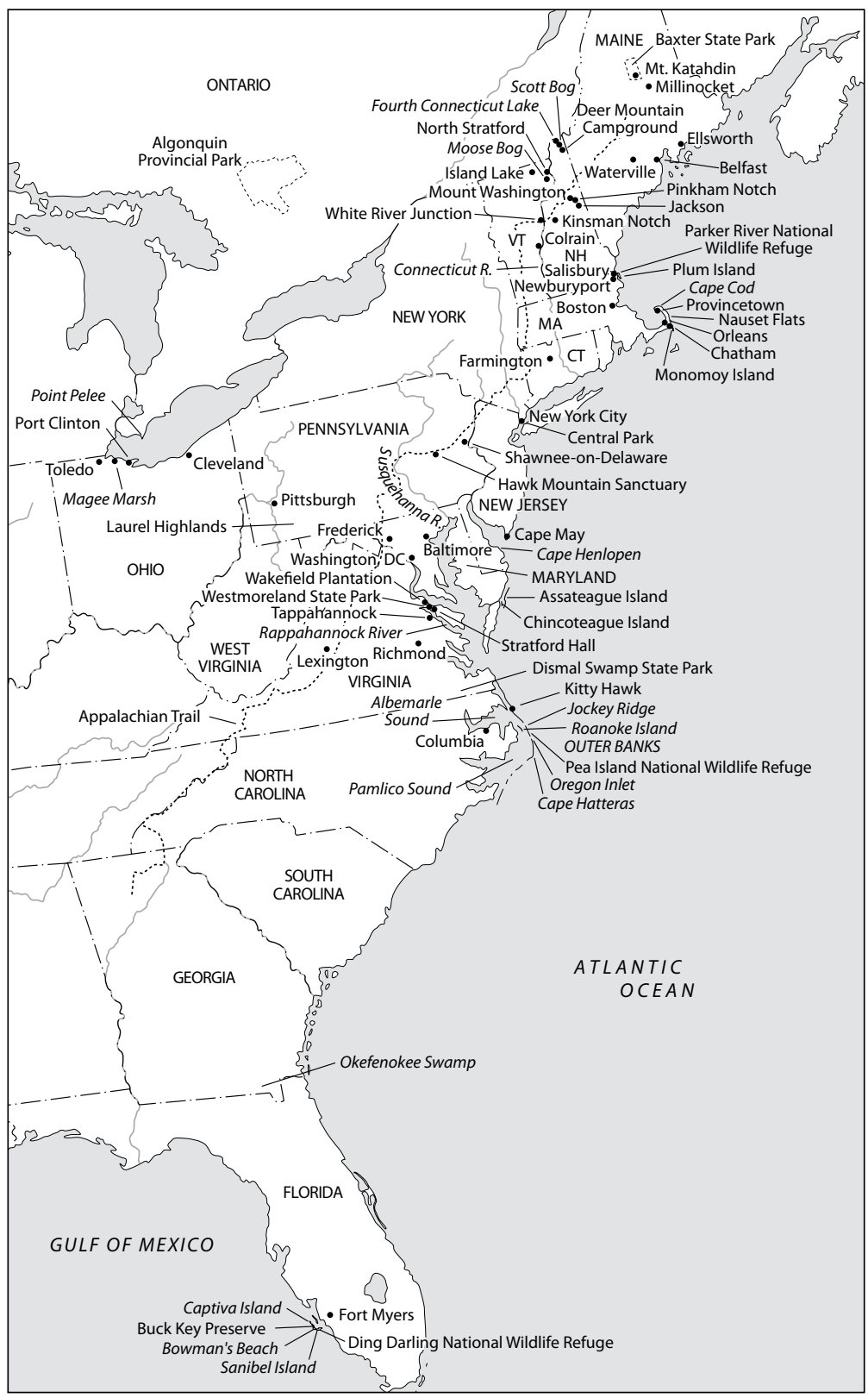

Locator map for East Coast sites visited 
Natural Encounters 
This page intentionally left blank 